\title{
Draining and salting as responsible key steps in the generation of the acid- forming potential of cheese: Application to a soft blue-veined cheese
}

\author{
Ecaterina Gore, Julie Mardon, ${ }^{1}$ and Annick Lebecque \\ Clermont University, VetAgro Sup, UPSP n²011-03-100, CALITYSS, 89 avenue Europe, F-63370 Lempdes, France
}

\begin{abstract}
A disregarded nutritional feature of cheeses is their high acid-forming potential when ingested, which is associated with deleterious effects on consumers' health. This work aimed to characterize the acid-forming potential of a blue-veined cheese during manufacturing to identify the main steps of the process involved in this phenomenon. Sampling was performed on 3 batches at 10 steps of the cheese-making process: reception of raw milk, pasteurization, maturation of milk, coagulation, stirring, draining of the curds, and 4 ripening stages: $21,28,42$, and $56 \mathrm{~d}$. The acid-forming potential of each sample was evaluated by (1) the calculation of the potential renal acid load (PRAL) index (considering protein, $\mathrm{Cl}, \mathrm{P}, \mathrm{Na}, \mathrm{K}, \mathrm{Mg}$, and Ca contents), and (2) its organic anion content (lactate and citrate), considered as alkalinizing elements. Draining and salting were identified as the main steps responsible for generation of the acid-forming potential of cheese. The draining process induced an increase in the PRAL index from $1.2 \mathrm{mEq} / 100 \mathrm{~g}$ in milk to $10.4 \mathrm{mEq} / 100 \mathrm{~g}$ in drained curds due to the increase in dry matter and the loss of alkaline minerals into the whey. The increase in PRAL value $(20.3 \mathrm{mEq} / 100 \mathrm{~g}$ at $\mathrm{d} 56)$ following salting resulted from an imbalance between the strong acidogenic elements $(\mathrm{Cl}, \mathrm{P}$, and proteins) and the main alkalinizing ones ( $\mathrm{Na}$ and $\mathrm{Ca}$ ). Particularly, $\mathrm{Cl}$ had a major effect on the PRAL value. Regarding organic anions, draining induced a loss of $93 \%$ of the citrate content in initial milk. The lactate content increased as fermentation occurred $(1,297.9 \mathrm{mg} / 100 \mathrm{~g}$ in drained curds), and then decreased during ripening (519.3 mg/100 $\mathrm{g}$ at $\mathrm{d} 56)$. This lactate level probably helps moderate the acidifying potential of end products. Technological strategies aimed at limiting the acid-forming potential of cheeses are proposed and deserve further research to evaluate their nutritional relevance.
\end{abstract}

Received February 26, 2016.

Accepted May 15, 2016.

${ }^{1}$ Corresponding author: julie.mardon@vetagro-sup.fr
Key words: acid-forming potential, cheese-making process, draining, salting, blue-veined cheese

\section{INTRODUCTION}

A disregarded nutritional feature of cheeses is their high acid-forming potential. This means that their intake may potentially induce an acid load to the body (Remer and Manz, 1994). The substantial consumption of cheese in Western diets (more than $20 \mathrm{~kg} / \mathrm{yr}$ per capita in France, Germany, Switzerland, and Italy; Fox and Guinee, 2013) justifies the study of this characteristic. Two dimensions should be considered for an extensive overview of the acid-forming or base-forming potential of a food product: (1) its potential renal acid load (PRAL) index, and (2) its organic anion content (Demigné et al., 2004a; Demigné, 2008; Gore et al., 2016).

The PRAL index was developed by Remer and Manz (1995) to evaluate the acid/alkaline load induced by foodstuffs when ingested. It is based on the nutrient composition of the product and is calculated as follows:

$$
\begin{aligned}
& \text { PRAL }(\mathrm{mEq} / 100 \mathrm{~g})=0.49 \times \operatorname{protein}(\mathrm{g} / 100 \mathrm{~g}) \\
& +0.037 \times \mathrm{P}(\mathrm{mg} / 100 \mathrm{~g})+0.027 \times \mathrm{Cl}(\mathrm{mg} / 100 \mathrm{~g}) \\
& -0.041 \times \mathrm{Na}(\mathrm{mg} / 100 \mathrm{~g})-0.021 \times \mathrm{K}(\mathrm{mg} / 100 \mathrm{~g}) \\
& -0.026 \times \mathrm{Mg}(\mathrm{mg} / 100 \mathrm{~g})-0.013 \times \mathrm{Ca}(\mathrm{mg} / 100 \mathrm{~g}) .
\end{aligned}
$$

Diet influences the acid-base balance of the body. Fixed acids are produced as the result of (1) the oxidation of the absorbed sulfur-containing AA from dietary proteins, (2) the generation of phosphates from the metabolism of phosphoesters and phosphoproteins, and (3) the absorption of chloride (Oh, 2000; Poupin et al., 2012). In contrast, ingested cations ( $\mathrm{Na}, \mathrm{Mg}$, $\mathrm{K}$, and $\mathrm{Ca}$ ), commonly assumed to be associated with metabolizable anions, have alkalinizing properties (Remer, 2001; Poupin et al., 2012). According to the calculation model, foods with positive PRAL denote an excess of acid-forming potential, whereas negative PRAL indicate an excess of alkaline-forming potential. 
Given their high positive PRAL values, cheeses may contribute to the development of low-grade metabolic acidosis (Remer and Manz, 1995; Cordain et al., 2005; Gore et al., 2016). In the long term, this state may have deleterious effects on renal function (Frassetto et al., 2007b; Fenton et al., 2011; Bonjour, 2013; Wang et al., 2015). Even if the hypothesis remains controversial because of the lack of well-designed clinical trials, bone and muscle tissues might be affected as well (New et al., 2004; Frassetto et al., 2008; Mardon et al., 2008; Pedone et al., 2010).

Citrate and lactate salt intakes may have an alkalinizing effect on the acid-base balance of the body (Demigné, 2008). When completely oxidized in the course of the metabolism, they are considered precursors of bicarbonate, an important alkalinizing component in the body (Oh, 2000; Poupin et al., 2012). Citrate is the most abundant organic anion in milk and lactate in cheese (Tormo and Izco, 2004). In cheeses, these organic anions result from biochemical changes during processing and ripening (Fox, 2004; McSweeney, 2004). Their contents depend on cheese type and on the existing microflora because lactate and citrate may follow different metabolic pathways (McSweeney and Sousa, 2000).

In their pioneering work, Remer and Manz (1995) found that milk and fresh cheeses were characterized by PRAL values around zero, whereas ripened cheeses exhibited high PRAL values. Demigné et al. (2004b) suggested that processing enhanced the acid-forming potential of cheese. This hypothesis was supported by Gore et al. (2016) who confirmed that different cheesemaking technologies had strong effects on acid-forming potentials of end products. In particular, they reported that hard cheeses and blue-veined cheeses exhibited the strongest acidogenic character. This was the result of a great imbalance between acidifying elements $(\mathrm{Cl}$, $\mathrm{P}$, and proteins) and alkalinizing ones ( $\mathrm{Na}$ and $\mathrm{Ca}$ ) of PRAL index.

Therefore, it would be interesting to study the evolution of the acid-forming potential of cheeses during manufacturing to determine the technological steps responsible for this acid-forming potential generation. This would allow us to better understand this feature, and potentially to control it. Indeed, in cheese-making technology, different end products are obtained through the modulation of various technological steps: milk setting, coagulum cutting, stirring, heating, draining, pressing, curd salting, or cheese ripening (Fox et al., 2004). All of these steps affect, to a varying degree, the final concentrations of various nutrients and thus influence the acid-forming potential of final products. To our knowledge, no work addressing this issue is reported in the literature. Some studies have focused on the evolution of certain minerals during the cheesemaking process (Moreno-Rojas et al., 1995; Cichoscki et al., 2002; González-Martín et al., 2011), but the lack of literature on this aspect is often criticized (Hickey et al., 2015) and these works do not allow evaluation of the PRAL index of intermediate and end products.

The aim of the present work was to determine the evolution of the acid-forming potential of cheese and its responsible key steps during the cheese-making process to characterize and better understand its generation. The study was based on the industrial cheese-making process (from raw milk to final stage of ripening) of a soft blue-veined cheese.

\section{MATERIALS AND METHODS}

\section{Cheese Manufacture}

Raw cow milk was pasteurized $\left(72^{\circ} \mathrm{C}, 15 \mathrm{~s}\right)$ and standardized in fat content $(3.8 \%)$, then cooled to $13^{\circ} \mathrm{C}$ (Figure 1). Calcium chloride (concentration $=520 \mathrm{~g} / \mathrm{L}$, volume $=15 \mathrm{~mL} / 100 \mathrm{~L}$ ) and fermented cocktail (starter culture and Penicillium roqueforti, volume $=0.6 \mathrm{~L} / 100$ L) were added for pre-maturation of milk for about 12 h. The milk was then heated to $32^{\circ} \mathrm{C}$ and moved to vats. Rennet extract (chymosin + pepsin, $\geq 160$ international milk clotting units $/ \mathrm{mL}$, volume $=30 \mathrm{~mL} / 100 \mathrm{~L}$ ) was added. After $30 \mathrm{~min}$ of incubation, the coagulum was cut into cubes $(1 \times 2 \times 2 \mathrm{~cm})$ using an automated cutting grid, and a stirring process for $1 \mathrm{~h}$ was applied to form grains of curd. A draining conveyor was used before molding so the grain structure was not damaged. The syneresis was carried out in molds, with periodic turnarounds, at a temperature between 19 and $20^{\circ} \mathrm{C}$. The curds were salted manually by rubbing dry salt on the surface and then pricked to allow the growth of Penicillium. Ripening was carried out at $8^{\circ} \mathrm{C}$ and $98 \%$ relative humidity until d 28 and thereafter at $0^{\circ} \mathrm{C}$ until d 56.

\section{Sampling}

Three cheese-making batches were prepared and manufactured at 1-wk intervals. The sampling was done during different steps of the cheese-making process: reception of raw milk, pasteurization, maturation of milk, coagulation, stirring, draining, and ripening. The raw milk represented a mixed milk from about 20 local producers, sampled before standardization and pasteurization. Pasteurized milk was sampled before adding the $\mathrm{CaCl}_{2}$ and the ferments and matured milk just before adding the rennet. One liter per batch was aliquoted 
and immediately frozen $\left(-20^{\circ} \mathrm{C}\right)$. The milk $(30 \mathrm{t})$ was distributed in 6 vats. Two vats were followed per batch: for each vat, $1 \mathrm{~L}$ of coagulum was sampled by immersing a jar into the vat, just before cutting, and $1 \mathrm{~L}$ of stirred grains of curd (SGC) was collected at the end of the draining conveyor. Samples were aliquoted and immediately frozen. Drained curds (DC) were sampled just before salting. During ripening, one salted blueveined cheese $(\mathbf{B C})$ per vat $(2.2 \mathrm{~kg}$ each $)$ was collected at various aging times: $21 \mathrm{~d}$ (BC21), $28 \mathrm{~d}$ (BC28), $42 \mathrm{~d}$ (BC42), and $56 \mathrm{~d}$ (BC56). Cheese samples were transported to the laboratory under refrigeration $\left(4^{\circ} \mathrm{C}\right)$, the rind of the ripened cheeses was removed and the cheeses were aliquoted and frozen (cooling cell, Tecnox, Strasbourg, France) at $-20^{\circ} \mathrm{C}$. All samples were kept in the freezer $\left(-20^{\circ} \mathrm{C}\right)$. One day before analysis, liquid samples from the 2 vats per batch were unfrozen in a refrigerator $\left(4^{\circ} \mathrm{C}\right)$ and pooled the day of analysis. Frozen solid samples were pooled and ground just before analysis to obtain a representative homogenized product and stored at $4^{\circ} \mathrm{C}$ until analysis.

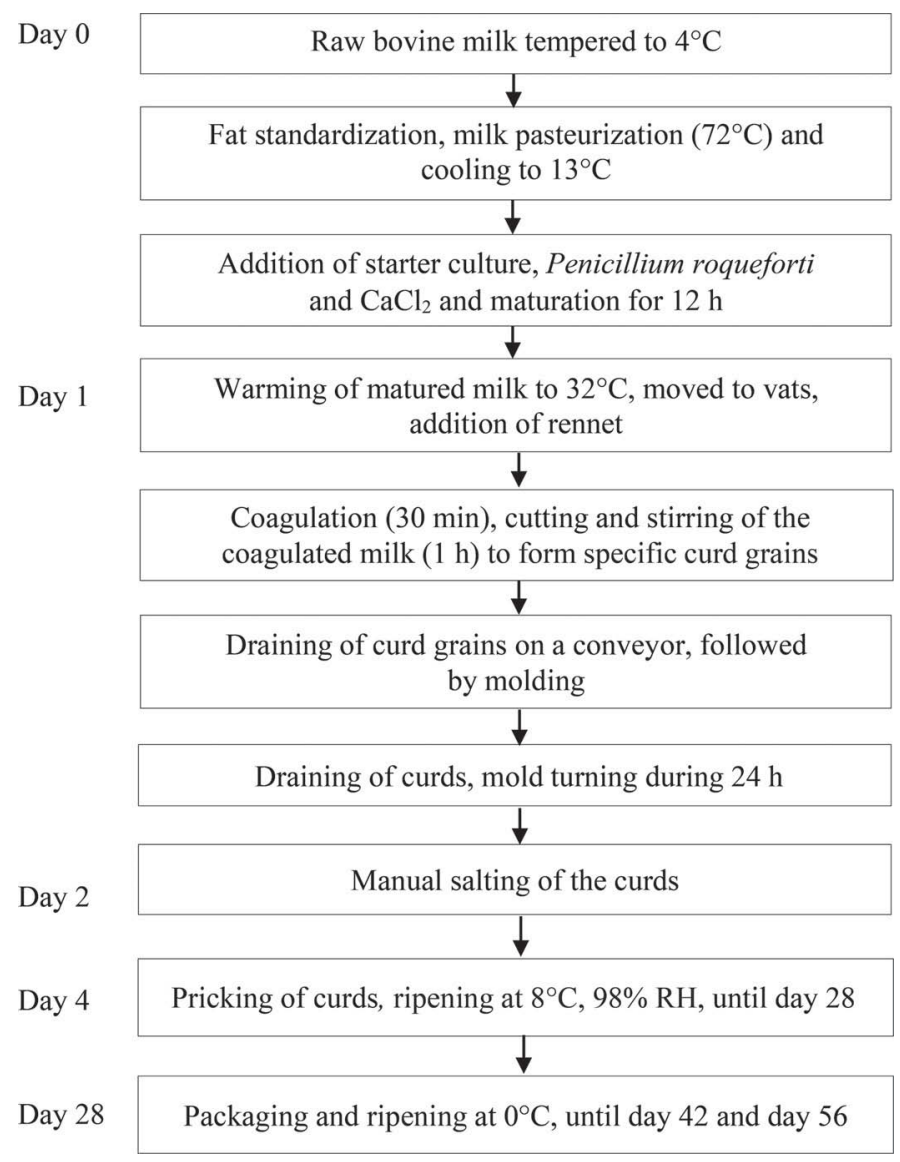

Figure 1. Manufacturing procedure for the studied blue-veined cheese.

\section{Basic Chemical Analysis}

Samples were analyzed in triplicate for $\mathrm{pH}$, DM, fat, ash, and protein according to ISO standards (AFNOR, 2013). The $\mathrm{pH}$ was measured at $20^{\circ} \mathrm{C}$ by using a food penetration $\mathrm{pH}$ measuring instrument (Testo 205, Testo, Alton, UK). The DM content was obtained by drying $3 \mathrm{~g}$ of product at $105^{\circ} \mathrm{C}$ in an oven for 24 $\mathrm{h}$ (ISO, 2004). The fat content was assayed using the Gerber method (ISO, 2000) and the ash content using a dry ash method (ISO, 1989). The total nitrogen was determined by Kjeldahl nitrogen analysis (ISO, 2013), using a Kjeldahl Unit (Büchi, Flawil, Switzerland). The amount of total $\mathrm{N}$ was multiplied by a factor of 6.38 to express the results in total protein.

\section{Mineral Determination (Calcium, Potassium, Magnesium, Sodium, and Phosphorus)}

The mineralization phase of $1 \mathrm{~g}$ of product was carried out in triplicate in a programmable oven (Fours Nagat, Bretagne, France), at $550^{\circ} \mathrm{C}$ for 6 h. The ashes obtained were dissolved in $1 \mathrm{~mL}$ of nitric acid $(25 \%$; VWR International, Fontenay-sous-Bois, France) and then made up to $250 \mathrm{~mL}$ with demineralized water. After appropriate dilution, the solution was injected in a Fast Sequential Atomic Absorption Spectrometer (Varian, AA240FS, Palo Alto, CA) according to ISO (2007a) to assay Ca, K, Mg, and Na contents. The total $\mathrm{P}$ was assessed with the colorimetric nitro-vanadomolybdate method from the same ash solution on a spectrophotometer (Secomam, Domont, France), at 430 $\mathrm{nm}$ wavelength as described by Bord et al. (2015).

\section{Analysis of Chloride, Citrate, and Lactate}

The $\mathrm{Cl}$ content in milk and cheese slurry was measured by potentiometric titration (Titroline Easy Potentiometer) with silver nitrate $0.1 N$ (VWR International) according to ISO (2007b).

The citrate and lactate contents were measured by enzymatic bio analysis (Enzytec Citric acid, Enzytec Lactic acid, R-Biopharm AG, Darmstadt, Germany), as described in the instructions supplied with the kit. Cheese samples $(5 \mathrm{~g})$ were homogenized in $50 \mathrm{~mL}$ of perchloric acid ( $1 \mathrm{M}$; VWR International, France) using an Ultra-Turrax homogenizer (IKA Labortechnik, Staufen im Breisgau, Germany). The homogenate was then centrifuged at $18,000 \times g$ for $10 \mathrm{~min}$ at $4^{\circ} \mathrm{C}$. The supernatant $(20 \mathrm{~mL})$ was adjusted to $\mathrm{pH} 8$ to 10 with approximatively $4 \mathrm{~mL}$ of $\mathrm{KOH}$ ( $5 \mathrm{M}$; VWR International, Leuven, Belgium) and placed for 15 min at $4^{\circ} \mathrm{C}$ for the quantitative precipitation of potassium perchlorate, 
and then filtered. The amount of NADH oxidized in the reactions of the filtrate with the different enzymes was determined by means of its light absorbance at 340 $\mathrm{nm}$ wavelength and was stoichiometric to the amount of citrate and lactate. For each product, the assay was performed in triplicate.

\section{Statistical Analysis}

Statistical analysis was performed using XL STAT software package (Addinsoft, Paris, France). Results are reported as means $( \pm \mathrm{SD})$. The Shapiro-Wilk $(P<$ $0.05)$ statistic was performed to check the normality of our data. A large segment of variables lacked normality and therefore nonparametric (Kruskal-Wallis) test and post hoc multiple comparison (Conover-Iman procedure) were adopted to compare the studied elements during the cheese-making process. Differences between mean values were considered significant at $P<0.05$.

\section{RESULTS}

\section{Changes in the Gross Composition}

Average $\mathrm{pH}$, DM, fat, ash, and protein contents of $\mathrm{BC}$ throughout cheese-making process are displayed in Table 1 . The $\mathrm{pH}$ of milk did not vary after standardization and pasteurization. A slight decrease was initiated during milk maturation and was intensified after coagulation with a marked acidification reported in $\mathrm{DC}(\mathrm{pH}=4.9)$. This trend reversed during ripening with an increase of $\mathrm{pH}$ until 6.2 in BC56. Dry matter, ash, and protein contents of milk remained unchanged until coagulation. This also holds true for fat content, once adjusted to $3.8 \mathrm{~g} / 100 \mathrm{~g}$ during standardization. As whey separation and evacuation (by cutting, stirring, and draining) occurred, all of these parameters significantly increased in curds to display at the end of ripening $54.1 \mathrm{~g} / 100 \mathrm{~g}$ of DM, $3.8 \mathrm{~g} / 100 \mathrm{~g}$ of ash, and $30.7 \mathrm{~g} / 100 \mathrm{~g}$ of fat. Particularly, the average milk protein content $(3.3 \mathrm{~g} / 100 \mathrm{~g})$ did not show any significant fluctuation until stirring $(8 \mathrm{~g} / 100 \mathrm{~g})$ and continued increasing after draining $(18.7 \mathrm{~g} / 100 \mathrm{~g})$ to reach a steady content of $20.6 \mathrm{~g} / 100 \mathrm{~g}$ during ripening.

\section{Evolution of Mineral Contents}

Table 2 shows the mineral evolution of $\mathrm{Ca}, \mathrm{P}, \mathrm{Mg}, \mathrm{K}$, $\mathrm{Na}$, and $\mathrm{Cl}$ contents of $\mathrm{BC}$ throughout cheese-making process. The $\mathrm{Ca}$ and $\mathrm{P}$ contents showed quite similar variations during the cheese-making process: no significant differences were observed until the coagulation of milk, and then both minerals increased significantly after the stirring process. Once the draining finished, Ca content remained unchanged until the end of ripening $(459.3 \mathrm{mg} / 100 \mathrm{~g})$. The $\mathrm{P}$ content reached a steady level during ripening as well $(302.1 \mathrm{mg} / 100 \mathrm{~g})$. Similar trends were observed for $\mathrm{Mg}$ during the preparation of the milk. The coagulation increased $\mathrm{Mg}$ content to $12.2 \mathrm{mg} / 100 \mathrm{~g}$ and the draining process to $19.5 \mathrm{mg} / 100$ $\mathrm{g}$, remaining constant until the end of ripening. The content of $\mathrm{K}$ remained relatively constant during the whole process, averaging $104.6 \mathrm{mg} / 100 \mathrm{~g}$ until draining and showing a tendency to decrease after the stirring and draining processes. Ripened cheeses exhibited K contents similar to those reported in initial raw milk. Initially low in both milk and curds, $\mathrm{Na}$ and $\mathrm{Cl}$ contents increased due to the salting process and reached a steady level during ripening.

\section{Lactate and Citrate Content Changes}

The lactate content of milk slightly increased after maturation until the molding process, ranging from 2.6

Table 1. Average $\mathrm{pH}$ and gross composition of raw milk (RM), pasteurized milk (PM), matured milk (MM), coagulum (C), stirred grains of curd (SGC), drained curds (DC), and blue-veined cheeses at various aging times: $21 \mathrm{~d}$ (BC21), $28 \mathrm{~d}$ (BC28), $42 \mathrm{~d}$ (BC42), and $56 \mathrm{~d}$ (BC56) of ripening (related to $100 \mathrm{~g}$ edible portion) $)^{1,2}$

\begin{tabular}{lccccc}
\hline Item & $\mathrm{pH}$ & DM $(\mathrm{g})$ & Fat $(\mathrm{g})$ & Ash $(\mathrm{g})$ & Protein $(\mathrm{g})$ \\
\hline RM & $6.8 \pm 0.1^{\mathrm{g}}$ & $12.8 \pm 0.1^{\mathrm{ab}}$ & $4.1 \pm 0.1^{\mathrm{b}}$ & $0.7 \pm 0.0^{\mathrm{a}}$ & $3.3 \pm 0.0^{\mathrm{a}}$ \\
$\mathrm{PM}$ & $6.8 \pm 0.1^{\mathrm{g}}$ & $12.5 \pm 0.3^{\mathrm{a}}$ & $3.8 \pm 0.1^{\mathrm{a}}$ & $0.7 \pm 0.0^{\mathrm{a}}$ & $3.3 \pm 0.1^{\mathrm{a}}$ \\
MM & $6.6 \pm 0.1^{\mathrm{fg}}$ & $12.5 \pm 0.2^{\mathrm{a}}$ & $3.8 \pm 0.1^{\mathrm{a}}$ & $0.7 \pm 0.0^{\mathrm{ab}}$ & $3.3 \pm 0.1^{\mathrm{a}}$ \\
$\mathrm{C}$ & $6.6 \pm 0.2^{\mathrm{fg}}$ & $13.5 \pm 0.7^{\mathrm{bc}}$ & $3.2 \pm 0.6^{\mathrm{a}}$ & $0.8 \pm 0.1^{\mathrm{bc}}$ & $3.5 \pm 0.3^{\mathrm{a}}$ \\
SGC & $6.5 \pm 0.3^{\mathrm{ef}}$ & $24.4 \pm 1.2^{\mathrm{cd}}$ & $14.4 \pm 5.4^{\mathrm{b}}$ & $1.2 \pm 0.0^{\mathrm{cd}}$ & $8.0 \pm 0.5^{\mathrm{b}}$ \\
DC & $4.9 \pm 0.4^{\mathrm{a}}$ & $49.7 \pm 3.2^{\mathrm{de}}$ & $28.4 \pm 1.2^{\mathrm{c}}$ & $2.3 \pm 0.6^{\mathrm{d}}$ & $18.7 \pm 0.6^{\mathrm{b}}$ \\
BC21 & $5.4 \pm 0.2^{\mathrm{ab}}$ & $53.7 \pm 0.6^{\mathrm{ef}}$ & $29.5 \pm 0.4^{\mathrm{cd}}$ & $3.7 \pm 0.2^{\mathrm{e}}$ & $20.3 \pm 0.4^{\mathrm{c}}$ \\
BC28 & $5.8 \pm 0.1^{\mathrm{bc}}$ & $54.7 \pm 0.8^{\mathrm{f}}$ & $30.1 \pm 0.2^{\mathrm{d}}$ & $3.9 \pm 0.4^{\mathrm{e}}$ & $20.6 \pm 0.4^{\mathrm{c}}$ \\
BC42 & $6.0 \pm 0.1^{\mathrm{cd}}$ & $54.0 \pm 1.0^{\mathrm{ef}}$ & $30.0 \pm 0.3^{\mathrm{d}}$ & $3.8 \pm 0.3^{\mathrm{e}}$ & $20.6 \pm 0.6^{\mathrm{c}}$ \\
BC56 & $6.2 \pm 0.2^{\mathrm{de}}$ & $54.1 \pm 1.3^{\mathrm{f}}$ & $30.7 \pm 0.7^{\mathrm{e}}$ & $3.8 \pm 0.2^{\mathrm{e}}$ & $20.6 \pm 0.7^{\mathrm{c}}$ \\
\hline
\end{tabular}

${ }^{\mathrm{a}-\mathrm{g}}$ Means in a column sharing common superscripts are similar as tested by Conover-Iman test $(P>0.05)$.

${ }^{1}$ Means of replicates $\pm \mathrm{SD}$.

${ }^{2}$ Kruskal-Wallis $P$-value $<0.0001$ in all cases. 
$\mathrm{mg} / 100 \mathrm{~g}$ for raw milk to $38.5 \mathrm{mg} / 100 \mathrm{~g}$ for SGC (Figure 2). A greater increase was observed in curds after 24 $\mathrm{h}$ of draining $(1,297.9 \mathrm{mg} / 100 \mathrm{~g})$. During the ripening period, the lactate content decreased significantly to $519.3 \mathrm{mg} / 100 \mathrm{~g}$. Inversely, the citrate content decreased significantly during the cheese-making process. Milk had the highest citrate content (100.5 mg/100 g), which decreased considerably during the draining process (to $6.1 \mathrm{mg} / 100 \mathrm{~g}$ ) and then remained constant.

\section{Evolution of PRAL Index}

Figure 3a shows the evolution of PRAL values during cheese-making process. During the first stages of manufacture, PRAL indexes of intermediate products were slightly over zero $(1.3 \mathrm{mEq} / 100 \mathrm{~g}$ on average). A first increase in PRAL index was reported between SGC $(3.4 \mathrm{mEq} / 100 \mathrm{~g})$ and DC $(10.4 \mathrm{mEq} / 100 \mathrm{~g})$, thus after draining. Then, the PRAL value increased dramatically at the salting step and the beginning of ripening (33.2 $\mathrm{mEq} / 100 \mathrm{~g}$ at $\mathrm{d} 21$ ). Finally, it reached a steady level in final stages of ripening $(20.3 \mathrm{mEq} / 100 \mathrm{~g})$. The SD values obtained after the stirring process showed important inter-batch variability, with ranges from 14.3 to $24.2 \mathrm{mEq} / 100 \mathrm{~g}$ for BC56.

The evolution of different PRAL elements (nutrient contents weighted with their conversion factors as defined by Remer and Manz, 1995) during the cheesemaking process are shown in Figure 3b. Until coagulation, the acidic elements of PRAL ( $\mathrm{Cl}, \mathrm{P}$, and protein) were compensated by the alkaline elements $(\mathrm{Na}, \mathrm{Ca}$, $\mathrm{K}$, and $\mathrm{Mg}$ ). Then, the draining process induced an increase in protein, $\mathrm{P}, \mathrm{Ca}$, and, to a lesser degree, in $\mathrm{Mg}$. At the same time, $\mathrm{K}, \mathrm{Cl}$, and $\mathrm{Na}$ remained constant. The strongest acidifying effect was observed just after the salting step, when $\mathrm{Cl}$ become the most acidic element of PRAL, due to its high concentrations. In $\mathrm{BC} 56, \mathrm{Cl}, \mathrm{P}$, and protein could not be counterbalanced by $\mathrm{Na}$ and $\mathrm{Ca}$, whereas $\mathrm{K}$ and $\mathrm{Mg}$ elements had little effect on the PRAL index, given their low concentrations.

\section{DISCUSSION}

This work, based on the study of a soft blue-veined cheese, investigated the generation of the acid-forming potential of cheese throughout processing. Indeed, this characteristic is known to be potentially associated with deleterious effects for consumers' health in the long term (Alexy et al., 2005; Frassetto et al., 2007b; Pedone et al., 2010). Thus, this study provides new data to better characterize and understand this nutritional feature. A full biochemical characterization was carried out from milk to final cheese during 10 steps of the process. Very few studies have reported similar exhaustive work (Moreno-Rojas et al., 1994). Most focused only on major minerals found in cheese and mainly during ripening of hard cheeses (Moreno-Rojas et al., 1995; Cichoscki et al., 2002). The results confirmed that cheese-making process was responsible for the high acid-forming potential of cheeses and allowed identification of draining and salting as the main key steps responsible for this characteristic.

\section{Effect of Draining}

Draining was the first step that significantly increased the PRAL index. First, the increase of DM as whey was expelled necessarily affected the PRAL value because it is expressed per $100 \mathrm{~g}$ of fresh product. Then, the

Table 2. Mineral composition of raw milk (RM), pasteurized milk (PM), matured milk (MM), coagulum (C), stirred grains of curd (SGC), drained curds (DC), and blue-veined cheeses at various aging times: $21 \mathrm{~d}$ (BC21), $28 \mathrm{~d}$ (BC28), $42 \mathrm{~d}$ (BC42), and 56 d (BC56) of ripening (related to $100 \mathrm{~g}$ edible portion)

\begin{tabular}{|c|c|c|c|c|c|c|}
\hline Item & \multicolumn{6}{|c|}{ Mineral element ${ }^{1,2}(\mathrm{mg} / 100 \mathrm{~g})$} \\
\hline RM & $96.3 \pm 18.0^{\mathrm{a}}$ & $48.2 \pm 30.7^{\mathrm{a}}$ & $8.0 \pm 2.0^{\mathrm{a}}$ & $100.2 \pm 19.3^{\mathrm{ab}}$ & $38.3 \pm 8.8^{\mathrm{a}}$ & $109.0 \pm 2.8^{\mathrm{bc}}$ \\
\hline MM & $100.8 \pm 13.4^{\mathrm{a}}$ & $72.1 \pm 24.2^{\mathrm{a}}$ & $8.2 \pm 1.1^{\mathrm{a}}$ & $99.2 \pm 15.9^{\mathrm{ab}}$ & $35.5 \pm 6.5^{\mathrm{a}}$ & $113.4 \pm 1.2^{\mathrm{cd}}$ \\
\hline $\mathrm{C}$ & $120.5 \pm 14.1^{\mathrm{ab}}$ & $76.1 \pm 19.9^{\mathrm{a}}$ & $12.2 \pm 2.0^{\mathrm{bc}}$ & $104.5 \pm 15.9^{\mathrm{b}}$ & $72.6 \pm 33.3^{\mathrm{b}}$ & $113.6 \pm 2.4^{\mathrm{d}}$ \\
\hline SGC & $222.8 \pm 39.5^{\mathrm{b}}$ & $158.9 \pm 27.9^{\mathrm{b}}$ & $14.8 \pm 3.2^{\mathrm{cd}}$ & $96.3 \pm 11.8^{\mathrm{ab}}$ & $93.0 \pm 29.5^{\mathrm{bc}}$ & $\begin{array}{l}110.0 \pm 2.4 \\
101.7 \pm 1.2^{\mathrm{a}}\end{array}$ \\
\hline $\begin{array}{l}\mathrm{D}-20 \\
\mathrm{BC} 42\end{array}$ & $443.9 \pm 48.9^{\mathrm{c}}$ & $375.1 \pm 20.1^{\mathrm{d}}$ & $23.6 \pm 2.6^{\mathrm{e}}$ & $104.3 \pm 16.6^{\mathrm{b}}$ & $743.7 \pm 117.3^{\mathrm{d}}$ & $1,459.6 \pm 124.9^{\mathrm{e}}$ \\
\hline BC56 & $459.3 \pm 24.3^{\mathrm{c}}$ & $302.1 \pm 72.3^{\mathrm{cd}}$ & $23.2 \pm 2.4^{\mathrm{e}}$ & $103.9 \pm 13.3^{\mathrm{ab}}$ & $755.8 \pm 82.7^{\mathrm{d}}$ & $1,436.9 \pm 141.8^{\mathrm{e}}$ \\
\hline
\end{tabular}


evolution of curds composition tightly depended on the phase in which components were located as syneresis and draining process occurred. Because of whey evacuation, casein micelles concentrated in curds, resulting in an increase in the protein element of PRAL (Figure $3 \mathrm{~b})$. At the same time, a large proportion of PRAL alkaline elements that were initially present in raw milk and mainly located in the aqueous phase of milk (Zamberlin et al., 2012) were lost. These losses were estimated at about $85 \%$ for $\mathrm{K}, 60 \%$ for $\mathrm{Mg}$, and $35 \%$ for $\mathrm{Ca}$ in the current work (data not shown). In DC, Ca and $\mathrm{P}$ concentrations increased in similar proportions because of their coexistence in casein micelles (Table 2). The level of remaining $\mathrm{Ca}$ and $\mathrm{P}$ bound in caseins is linked to coagulum acidification: the higher the coagulum acidification level before draining, the more Ca and $\mathrm{P}$ are lost into the whey (Le Graet and Brule, 1993). In cow milk, the complete solubilization of inorganic
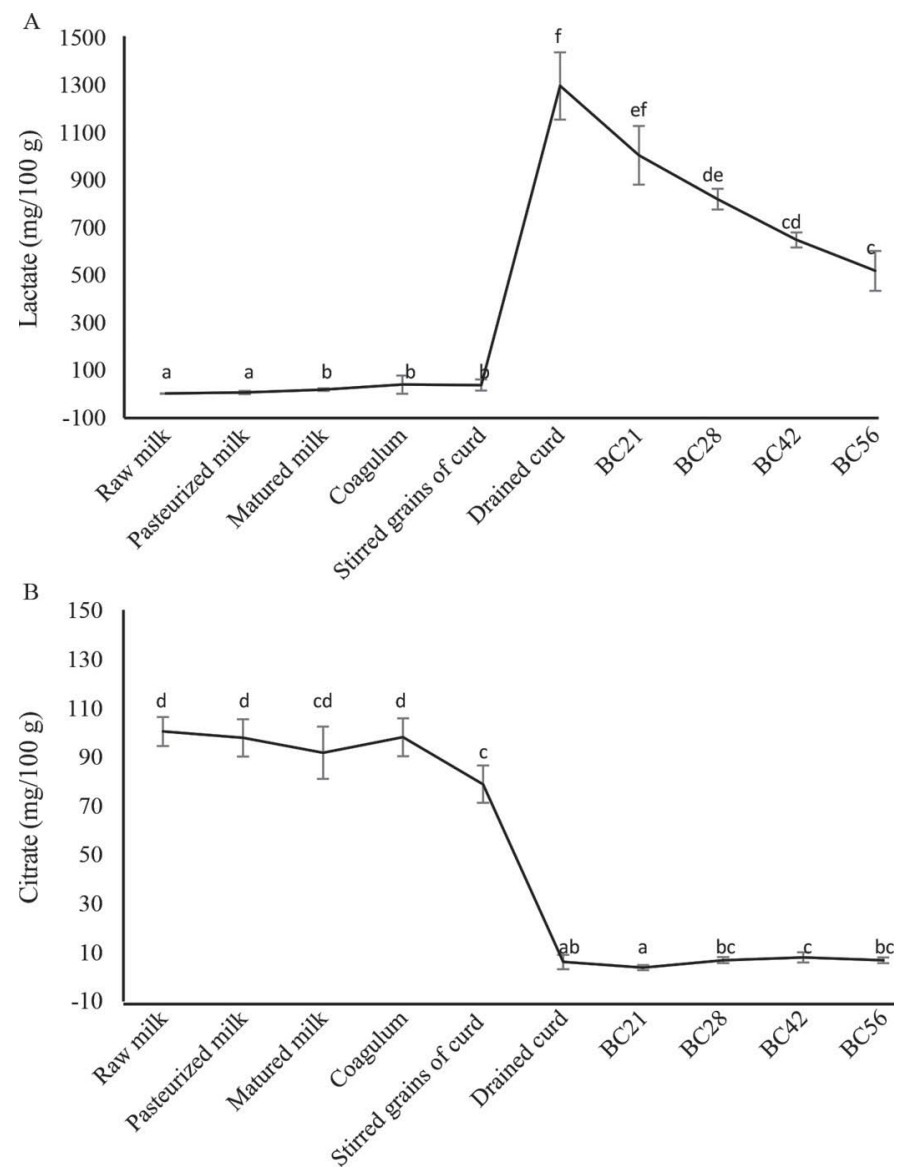

Figure 2. Evolution of lactate and citrate contents throughout cheese-making process of blue-veined cheese (related to $100 \mathrm{~g}$ of edible portion). The data represent means $\pm \mathrm{SD} ; \mathrm{n}=9$. Kruskal-Wallis $P$-value $<0.0001$. Means sharing common letters $(\mathrm{a}-\mathrm{f})$ are similar as tested by Conover-Iman test $(P>0.05)$. Blue-veined cheeses at various aging times: $21 \mathrm{~d}$ (BC21), $28 \mathrm{~d}$ (BC28), $42 \mathrm{~d}$ (BC42), and $56 \mathrm{~d}$ (BC56) of ripening.
$\mathrm{P}$ is attained at $\mathrm{pH} 5.2$, whereas $\mathrm{Ca}$ solubilizes at $\mathrm{pH}$ 3.5 (Le Graet and Brule, 1993; Reykdal et al., 2011). In the current work, the slow draining $(24 \mathrm{~h})$ involved acidification of the curds to a $\mathrm{pH}$ of 4.9 , explaining the detected loss of minerals in DC. The resulting increase in PRAL index $(10.4 \mathrm{mEq} / 100 \mathrm{~g})$ was due to the imbalance between the important weight of acidogenic elements $\mathrm{P}$ and proteins and the main alkalinizing element (Ca). Given its low concentration compared with $\mathrm{Ca}$ and $\mathrm{P}, \mathrm{Mg}$ poorly affected PRAL values. Potassium contents remained constant, and thus had few consequences on PRAL variations.

\section{Effect of Salting}

Salting induced a dramatic increase in the acidforming potential of cheese during processing, with a

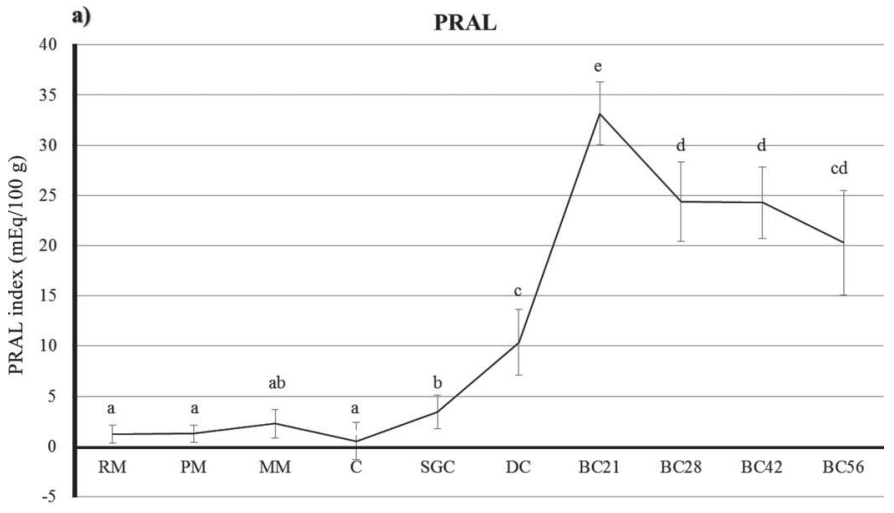

PRAL $(\mathrm{mEq} / 100 \mathrm{~g})=0.49 \times$ protein $(\mathrm{g} / 100 \mathrm{~g})+0.037 \times \mathrm{P}(\mathrm{mg} / 100 \mathrm{~g})+0,027 \mathrm{x} \mathrm{Cl}(\mathrm{mg} / 100 \mathrm{~g})-0,041 \mathrm{x}$ $\mathrm{Na}(\mathrm{mg} / 100 \mathrm{~g})-0.021 \times \mathrm{K}(\mathrm{mg} / 100 \mathrm{~g})-0.026 \times \mathrm{Mg}(\mathrm{mg} / 100 \mathrm{~g})-0.013 \times \mathrm{Ca}(\mathrm{mg} / 100 \mathrm{~g})$

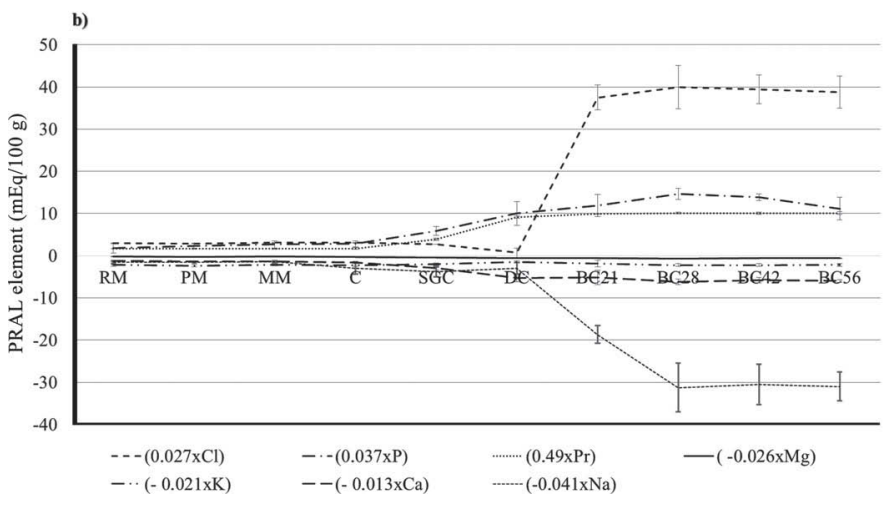

Figure 3. Evolution of potential renal acid load (PRAL) index (a) and PRAL elements weighted with their derived factors (b) during the manufacture of blue-veined cheese. The data represent means $\pm \mathrm{SD}$, expressed in $\mathrm{mEq} / 100 \mathrm{~g}$ edible portions; $\mathrm{n}=9$. Kruskal-Wallis $P$-value $<0.0001$ in all cases. Means sharing common letters (a-d) are similar as tested by Conover-Iman test $(P>0.05)$. Raw milk $(\mathrm{RM})$, pasteurized milk $(\mathrm{PM})$, matured milk (MM), coagulum $(\mathrm{C})$, stirred grains of curd (SGC), drained curds (DC), and blue-veined cheeses at various aging times: $21 \mathrm{~d}$ (BC21), $28 \mathrm{~d}$ (BC28), $42 \mathrm{~d}$ (BC42), and $56 \mathrm{~d}$ (BC56) of ripening; Pr, protein. 
PRAL value tripled between DC and BC21 (Figure 3a). The study of PRAL element changes (Figure $3 \mathrm{~b}$ ) from salting revealed that $\mathrm{Cl}$ and $\mathrm{Na}$ elements had a strong effect on the PRAL value compared with others. Particularly, $\mathrm{Cl}$ element, given its high content (Table 2), had a strong acidogenic effect, resulting in an increase in the PRAL index. Similar situations were described by Remer and Manz (1995) in Cheddar-type cheese and Parmesan. This point highlighted the interest of considering $\mathrm{Na}$ and $\mathrm{Cl}$ in PRAL calculation for cheeses. Indeed, it is noteworthy that, from 2003, $\mathrm{Na}$ and $\mathrm{Cl}$ were omitted from the PRAL formula when estimating a diet-dependent net acid load (Remer, 2003; Frassetto et al., 2007a). Indeed, $\mathrm{Na}$ and $\mathrm{Cl}$ were found to fully compensate in several clinical studies when the urinary cation-anion difference was calculated (Remer and Manz, 1994). This change accounted for missing $\mathrm{Cl}$ data from food tables and assumed that, in the case of processed salted foods, $\mathrm{Na}$ and $\mathrm{Cl}$ would always have a stoichiometric relationship, with equal concentrations. However, in cheese-making technology, $\mathrm{Cl}$ ions in milk, and later in cheese whey, are accompanied by either $\mathrm{Na}$ or other cations. Salt is added during processing and a portion of $\mathrm{Na}$ and $\mathrm{Cl}$ ions are allowed to drain off into the whey. Therefore, $\mathrm{Na}$ and $\mathrm{Cl}$ concentrations changes are unlikely to be stoichiometric and this is supported in the current work. In the literature, very few works addressed the distribution of $\mathrm{Cl}$ and $\mathrm{Na}$ in cheese matrix to understand this feature (Hardy, 1983, 1976; Boisard et al., 2013). The diffusion of salt has been studied (Morris et al., 1985), but $\mathrm{NaCl}$ content is still mainly considered from the $\mathrm{Cl}$ determination (Floury et al., 2009; McMahon et al., 2009; Fucà et al., 2012).

Overall, the cumulative effects of main alkalinizing elements ( $\mathrm{Na}$ and $\mathrm{Ca}$ ) could not compensate the strong acidogenic elements $(\mathrm{Cl}, \mathrm{P}$, and proteins) and resulted in a high mean PRAL index at d $56(20.3 \mathrm{mEq} / 100$ $\mathrm{g})$. This value is in agreement with previous studies in blue cheese (Gore et al., 2016) and is comparable with the PRAL calculated by Remer and Manz (1995) in hard cheeses. Contrary to what is often found in the literature (Remer and Manz, 1995; Alexy et al., 2005), the acidogenic character of dietary proteins needs to be moderated for cheeses; the current work highlights the fact that $\mathrm{Cl}$ is the strongest acidifying nutrient in the end product and that $\mathrm{P}$ is at least as acidifying as proteins.

\section{Effect of Cheese-Making Process on Organic Anion Content}

During the cheese-making process, biochemical changes due to metabolism of lactose, lactate, and ci- trate are likely to modulate the acid-forming potential of cheese (Demigné et al., 2004a). In the body, metabolizable organic anions (lactate, citrate), in the form of salts, are effectively absorbed in the small intestine. They are metabolized mostly in the liver to lead to the synthesis of bicarbonate, a powerful buffer system in the organism (Oh, 2000; Poupin et al., 2012). Thus, food products with valuable contents in metabolizable organic anions are assumed to contribute to the neutralization of the fixed acidity of the body (Demigné et al., 2004a; Sabboh et al., 2007). The daily food supply of organic anions is recognized to be dependent on fruit and vegetable intake. Nevertheless, animal foods represent a nonnegligible source of organic anions. In subjects consuming a diet high in meat and dairy products, animal foods are probably the main contributors to organic anion intake (Demigné et al., 2004a).

During processing, the activity of the mesophilic starter bacteria resulted in a large increase in lactate (Figure 2), which may be further metabolized to various compounds (cheese flavor). This metabolization is particularly extensive in surface mold-ripened and blue-veined cheeses (McSweeney and Sousa, 2000), and would initially involve Geotrichum candidum, followed by Penicillium roqueforti (McSweeney, 2004). In $\mathrm{BC}$, the decrease in lactate content by $27.5 \%$ in $\mathrm{BC} 21$ and by $62.6 \%$ in BC56 compared with that in DC was consistent with this phenomenon. We hypothesize that lactate rate might continue to decrease with a longer ripening time. Nevertheless, if consumed at $28 \mathrm{~d}$ of ripening, the BC, containing $820 \mathrm{mg}$ of lactate per $100 \mathrm{~g}$, can be considered as a lactate-rich food product, compared with the semi-hard cheeses Comte and Emmental (Mullin and Emmons, 1997). At 28 d, one portion of $40 \mathrm{~g}$ of $\mathrm{BC}$ is richer in organic anions than $100 \mathrm{~g}$ of vegetables (Demigné, 2008).

Milk contained about $100.5 \mathrm{mg} / 100 \mathrm{~g}$ of citrate. Most of it was lost in the whey during the cheese-making process (Figure 2), as described by McSweeney and Sousa (2000). A part of the remaining citrate was also reported to be possibly metabolized by nonstarter lactic acid bacteria (McSweeney, 2004). In the blue-veined cheese studied, only $6.8 \%$ of the initial citrate content remained in BC56 (6.8 $\pm 1.2 \mathrm{mg} / 100 \mathrm{~g})$. Thus, even if citrate theoretically has a 3 -fold higher alkalinizing effect than lactate in the body due to its 3 carboxyl groups, the low citrate content in ripened cheese makes its base-forming potential negligible compared with lactate.

\section{Implications}

These results could be useful to develop strategies aiming to reduce the acid-forming potential of cheeses: 
- An important track to investigate would be the modulation of the salting process. In agreement with the public health recommendation to decrease salt consumption, it would be relevant to apply partial replacement of $\mathrm{NaCl}$. Salt substitution is a practice already widely used (Grummer et al., 2012, 2013; Lu and McMahon, 2015). However, most of these works explored the use of $\mathrm{CaCl}_{2}$ or $\mathrm{KCl}$ as $\mathrm{NaCl}$ substitutes, both of which induce an acid load to the body (Remer, 2001).

- Calcium enrichment might be a relevant approach to consider. It could counterbalance the alkaline element loss occurring during draining, especially $\mathrm{Ca}$ (35\% of initial $\mathrm{Ca}$ in raw milk is lost into the whey), and thus neutralize the acidogenic effect of $\mathrm{P}$.

- The investigation of lactate content fluctuations suggests that a consumption of blue cheese with a short ripening time would better limit its acidforming potential rather than products with longer ripening time.

However, such interventions would require better control of PRAL variations. Indeed, this work highlights the fact that acid-forming potential of cheese is subjected to inter-batch variations in mineral composition, especially in $\mathrm{Na}$ and $\mathrm{Cl}$ contents. Similar wide fluctuations were previously reported in cheeses involving mold growth and were assigned to the development of Penicillium (Gaucheron et al., 1999; Prieto et al., 2000; Abbas, 2012). To clarify this limitation, further research would be needed on cheeses produced with different processes. This work was carried out on a limited number of productions and in one single cheese type. Further investigations are needed to extrapolate the results to other cheeses. In particular, hard cheeses would be an interesting product to investigate because they have high PRAL values (Remer and Manz, 1995; Gore et al., 2016) but also show great lactate contents.

Another limitation of this work is that, the PRAL formula was developed for use in all foodstuffs, not specifically for cheeses. Thus, it is unclear whether the mean intestinal absorption rate of $\mathrm{Ca}(25 \%)$ and $\mathrm{P}$ $(63 \%)$ in particular are suitable. Indeed, depending on the cheese matrix, $\mathrm{Ca}$ and $\mathrm{P}$ chemical forms in cheeses can be different, which might modulate their bioavailability (Buchowski and Miller, 1990; Cashman, 2002). On the other hand, even though we emphasize that lactate content might affect the acid-forming potential of cheeses, we cannot determine from this study how anion contents should be used in the PRAL formula. This issue deserves clinical investigations to determine the respective weight of PRAL and organic anion con- tents in the acid-forming potential of food products. Clinical studies should also be undertaken to perform a direct measurement of the urinary acid excretion. This would allow a more reliable evaluation of the generated net acid load to the metabolic system.

\section{CONCLUSIONS}

The present study demonstrates the acidogenic character of the cheese-making process. The main steps responsible for this characteristic were identified: the draining process, because of the loss of alkaline minerals $(\mathrm{Ca}, \mathrm{Mg}, \mathrm{Na}, \mathrm{K})$ in the whey as well as the concentration of casein micelles in curds, and the salting process, because of the imbalance between the strong acidifying effect of $\mathrm{Cl}, \mathrm{P}$, and protein on the one hand, and $\mathrm{Na}$ and $\mathrm{Ca}$ on the other hand. However, the relatively high lactate content in blue-veined cheese during fermentation could partly counteract the PRAL value of the cheese. This paper opens new perspectives regarding strategies for nutritional optimization of cheeses and provides new data on their nutritional functionalities. This area deserves further research, notably to evaluate the eventuality and nutritional consistency to limit the acid-forming potential of cheeses.

\section{ACKNOWLEDGMENTS}

The research was co-financed by FEDER (European Regional Development Funds) in Auvergne (France). The authors declared no potential conflicts of interest with respect to the research, authorship, or publication of this article.

\section{REFERENCES}

Abbas, K. 2012. Effet de traitements thermiques sur les propriétés fonctionnelles de fromages traditionnels : le cas des pâtes persillées (These). Agricultural Sciences. Blaise Pascal University, ClermontFerrand, France.

AFNOR. 2013. Association française de normalisation. Chemical analysis. Accessed Nov. 9, 2015. http://sagaweb.afnor.org/fr-FR/sw/ Identification/AccueilAbonnement.

Alexy, U., T. Remer, F. Manz, C. M. Neu, and E. Schoenau. 2005. Long-term protein intake and dietary potential renal acid load are associated with bone modeling and remodeling at the proximal radius in healthy children. Am. J. Clin. Nutr. 82:1107-1114.

Boisard, L., I. Andriot, C. Arnould, C. Achilleos, C. Salles, and E. Guichard. 2013. Structure and composition of model cheeses influence sodium NMR mobility, kinetics of sodium release and sodium partition coefficients. Food Chem. 136:1070-1077.

Bonjour, J.-P. 2013. Nutritional disturbance in acid-base balance and osteoporosis: A hypothesis that disregards the essential homeostatic role of the kidney. Br. J. Nutr. 110:1168-1177.

Bord, C., D. Guerinon, and A. Lebecque. 2015. Impact of heating on sensory properties of French Protected Designation of Origin (PDO) blue cheeses. Relationships with physicochemical parameters. Food Sci. Technol. Int. http://dx.doi.org/10.1177/1082013215605201. 
Buchowski, M. S., and D. D. Miller. 1990. Calcium bioavailability from ripening Cheddar cheese. J. Food Sci. 55:1293-1295.

Cashman, K. D. 2002. Calcium intake, calcium bioavailability and bone health. Br. J. Nutr. 87:S169-S177.

Cichoscki, A. J., E. Valduga, A. T. Valduga, M. E. Tornadijo, and J. M. Fresno. 2002. Characterization of Prato cheese, a Brazilian semi-hard cow variety: Evolution of physico-chemical parameters and mineral composition during ripening. Food Contr. 13:329-336.

Cordain, L., S. B. Eaton, A. Sebastian, N. Mann, S. Lindeberg, B. A. Watkins, J. H. O'Keefe, and J. Brand-Miller. 2005. Origins and evolution of the Western diet: Health implications for the 21st century. Am. J. Clin. Nutr. 81:341-354.

Demigné, C. 2008. Fonctionnalité alcalinisante. Pages 541-558 in Aliments Fonctionnels. 2nd ed. Lavoisier, Paris, France.

Demigné, C., H. Sabboh, C. Puel, C. Rémésy, and V. Coxam. 2004a. Organic anions and potassium salts in nutrition and metabolism. Nutr. Res. Rev. 17:249-258.

Demigné, C., H. Sabboh, C. Rémésy, and P. Meneton. 2004b. Protective effects of high dietary potassium: Nutritional and metabolic aspects. J. Nutr. 134:2903-2906.

Fenton, T. R., S. C. Tough, A. W. Lyon, M. Eliasziw, and D. A. Hanley. 2011. Causal assessment of dietary acid load and bone disease: A systematic review \& meta-analysis applying Hill's epidemiologic criteria for causality. Nutr. J. 10:41.

Floury, J., O. Rouaud, M. Le Poullennec, and M.-H. Famelart. 2009. Reducing salt level in food: Part 2. Modelling salt diffusion in model cheese systems with regards to their composition. LWT Food Sci. Technol. (Campinas.) 42:1621-1628.

Fox, P. F. 2004. Cheese: General aspects. Elsevier Academic Press, San Diego, CA.

Fox, P. F., and T. P. Guinee. 2013. Cheese Science and Technology. Pages 357-389 in Milk and Dairy Products in Human Nutrition. Young Park and George Haenlein, ed. Oxford, UK

Fox, P. F., P. L. H. McSweeney, T. M. Cogan, and T. P. Guinee. 2004. Cheese: Chemistry, Physics and Microbiology: Major Cheese Groups. Elsevier Academic Press, Oxford, UK.

Frassetto, L. A., S. Lanham-New, H. M. Macdonald, T. Remer, A. Sebastian, K. L. Tucker, and F. A. Tylavsky. 2007a. Standardizing terminology for estimating the diet-dependent net acid load to the metabolic system. J. Nutr. 137:1491-1492.

Frassetto, L. A., C. Morris, and A. Sebastian. 2007b. Dietary sodium chloride intake independently predicts the degree of hyperchloremic metabolic acidosis in healthy humans consuming a net acidproducing diet. Am. J. Physiol. Renal Physiol. 293:F521-F525.

Frassetto, L. A., R. Morris, D. Sellmeyer, and A. Sebastian. 2008. Adverse effects of sodium chloride on bone in the aging human population resulting from habitual consumption of typical American diets. J. Nutr. 138:419S-422S.

Fucà, N., D. J. McMahon, M. Caccamo, L. Tuminello, S. La Terra, M. Manenti, and G. Licitra. 2012. Effect of brine composition and brining temperature on cheese physical properties in Ragusano cheese. J. Dairy Sci. 95:460-470.

Gaucheron, F., Y. Le Graët, F. Michel, V. Briard, and M. Piot. 1999. Evolution of various salt concentrations in the moisture and in the outer layer and centre of a model cheese during its brining and storage in an ammoniacal atmosphere. Lait 79:553-566.

González-Martín, I., J. M. Hernández-Hierro, I. Revilla, A. VivarQuintana, and I. Lobos Ortega. 2011. The mineral composition ( $\mathrm{Ca}, \mathrm{P}, \mathrm{Mg}, \mathrm{K}, \mathrm{Na}$ ) in cheeses (cow's, ewe's and goat's) with different ripening times using near infrared spectroscopy with a fibreoptic probe. Food Chem. 127:147-152.

Gore, E., J. Mardon, D. Guerinon, and A. Lebecque. 2016. Exploratory study of acid-forming potential of commercial cheeses: Impact of cheese type. Int. J. Food Sci. Nutr. 67:412-421. http://dx.doi.or $\mathrm{g} / 10.3109 / 09637486.2016 .1166188$.

Grummer, J., N. Bobowski, M. Karalus, Z. Vickers, and T. Schoenfuss. 2013. Use of potassium chloride and flavor enhancers in low sodium Cheddar cheese. J. Dairy Sci. 96:1401-1418.

Grummer, J., M. Karalus, K. Zhang, Z. Vickers, and T. C. Schoenfuss. 2012. Manufacture of reduced-sodium Cheddar-style cheese with mineral salt replacers. J. Dairy Sci. 95:2830-2839.
Hardy, J. 1976. Etude de la duffusion du sel dans les fromages à pate molle de type Camembert. Comparaison du salage à sec et du salage en saumure. Thesis. Université de Nancy, Nancy, France.

Hardy, J. 1983. Diffusion et distribution du chlorure de sodium dans les fromages. Influence sur l'activité de l'eau et les propriétés de sorption de l'eau. Thesis. Institut National Polytechnique de Lorraine, Nancy, France.

Hickey, C. D., M. A. E. Auty, M. G. Wilkinson, and J. J. Sheehan. 2015. The influence of cheese manufacture parameters on cheese microstructure, microbial localisation and their interactions during ripening: A review. Trends Food Sci. Technol. 41:135-148.

ISO. 2004. ISO 5530:2004. Determination of the total solids content. (Reference method). International Organization for Standardization, Geneva, Switzerland.

ISO. 1989. ISO 208:1989. Determination of ash content. International Organization for Standardization, Geneva, Switzerland.

ISO. 2007a. ISO 8070:2007. Determination of calcium, sodium, potassium and magnesium contents. International Organization for Standardization, Geneva, Switzerland.

ISO. 2007b. ISO 5943:2007. Determination of chloride content. International Organization for Standardization, Geneva, Switzerland.

ISO. 2000. ISO 210:2000. Milk-Determination of fat content-Acidobutyrometric (Gerber method). International Organization for Standardization, Geneva, Switzerland.

ISO. 2013. ISO 8968-1:2013. Milk and milk products-Determination of nitrogen content-Part 1: Kjeldahl principle and crude protein calculation. International Organization for Standardization, Geneva, Switzerland.

Le Graet, Y., and G. Brule. 1993. Effects of pH and ionic strength on distribution of mineral salts in milk. Lait 73:51-60.

Lu, Y., and D. J. McMahon. 2015. Effects of sodium chloride salting and substitution with potassium chloride on whey expulsion of Cheddar cheese. J. Dairy Sci. 98:78-88.

Mardon, J., V. Habauzit, A. Trzeciakiewicz, M.-J. Davicco, P. Lebecque, S. Mercier, J.-C. Tressol, M.-N. Horcajada, C. Demigné, and V. Coxam. 2008. Long-term intake of a high-protein diet with or without potassium citrate modulates acid-base metabolism, but not bone status, in male rats. J. Nutr. 138:718-724.

McMahon, D. J., M. M. Motawee, and W. R. McManus. 2009. Influence of brine concentration and temperature on composition, microstructure, and yield of feta cheese. J. Dairy Sci. 92:4169-4179.

McSweeney, P. L. H. 2004. Biochemistry of cheese ripening. Int. J. Dairy Technol. 57:127-144.

McSweeney, P. L. H., and M. J. Sousa. 2000. Biochemical pathways for the production of flavour compounds in cheeses during ripening: A review. Lait 80:293-324.

Moreno-Rojas, R., M. A. Amaro-Lopez, R. H. Garcia-Gimeno, and G. Zurera-Cosano. 1995. Effects of Manchego-type cheese-making process on contents of mineral elements. Food Chem. 53:435-439.

Moreno-Rojas, R., R. Pozo-Lora, G. Zurera-Cosano, and M. A. Amaro-Lopez. 1994. Calcium, magnesium, manganese, sodium and potassium variations in Manchego-type cheese during ripening. Food Chem. 50:373-378.

Morris, H. A., T. P. Guinee, and P. F. Fox. 1985. Salt diffusion in Cheddar cheese. J. Dairy Sci. 68:1851-1858.

Mullin, W. J., and D. B. Emmons. 1997. Determination of organic acids and sugars in cheese, milk and whey by high performance liquid chromatography. Food Res. Int. 30:147-151.

New, S. A., H. M. MacDonald, M. K. Campbell, J. C. Martin, M. J. Garton, S. P. Robins, and D. M. Reid. 2004. Lower estimates of net endogenous noncarbonic acid production are positively associated with indexes of bone health in premenopausal and perimenopausal women. Am. J. Clin. Nutr. 79:131-138.

Oh, M. S. 2000. Acid-base in renal failure: New perspectives on acidbase balance. Semin. Dial. 13:212-219.

Pedone, C., N. Napoli, P. Pozzilli, F. Lauretani, S. Bandinelli, L. Ferrucci, and R. Antonelli-Incalzi. 2010. Quality of diet and potential renal acid load as risk factors for reduced bone density in elderly women. Bone 46:1063-1067. 
Poupin, N., J. Calvez, C. Lassale, C. Chesneau, and D. Tomé. 2012. Impact of the diet on net endogenous acid production and acidbase balance. Clin. Nutr. 31:313-321.

Prieto, B., I. Franco, J. M. Fresno, A. Bernardo, and J. Carballo. 2000. Picón Bejes-Tresviso blue cheese: An overall biochemical survey throughout the ripening process. Int. Dairy J. 10:159-167.

Remer, T. 2001. Influence of nutrition on acid-base balance-metabolic aspects. Eur. J. Nutr. 40:214-220.

Remer, T. 2003. High meat diet, acid-base status and calcium retention. J. Nutr. 133:3239

Remer, T., and F. Manz. 1994. Estimation of the renal net acid excretion by adults consuming diets containing variable amounts of protein. Am. J. Clin. Nutr. 59:1356-1361.

Remer, T., and F. Manz. 1995. Potential renal acid load of foods and its influence on urine pH. J. Am. Diet. Assoc. 95:791-797.

Reykdal, O., S. Rabieh, L. Steingrimsdottir, and H. Gunnlaugsdottir. 2011. Minerals and trace elements in Icelandic dairy products and meat. J. Food Compos. Anal. 24:980-986.
Sabboh, H., V. Coxam, M.-N. Horcajada, C. Rémésy, and C. Demigné 2007. Effects of plant food potassium salts (citrate, galacturonate or tartrate) on acid-base status and digestive fermentations in rats. Br. J. Nutr. 98:72-77.

Tormo, M., and J. M. Izco. 2004. Alternative reversed-phase high-performance liquid chromatography method to analyse organic acids in dairy products. J. Chromatogr. A 1033:305-310.

Wang, O., Y. Hu, S. Gong, Q. Xue, Z. Deng, L. Wang, H. Liu, H. Tang, X. Guo, J. Chen, X. Jia, Y. Xu, L. Lan, C. Lei, H. Dong, G. Yuan, Q. Fu, Y. Wei, W. Xia, and L. Xu. 2015. A survey of outcomes and management of patients post fragility fractures in China. Osteoporos. Int. 26:2631-2640.

Zamberlin, S., N. Antunac, J. Havranek, and D. Samarzija. 2012. Mineral elements in milk and dairy products. Mljekarstvo 62:111-125. 